\title{
Aneta Nietupska
}

Uniwersytet Ekonomiczny we Wrocławiu

e-mail: aneta.nietupska@interia.pl

\section{WPLYW ZMIAN DEMOGRAFICZNYCH \\ NA EKONOMICZNE ZABEZPIECZENIE STAROŚCI SPOLECZEŃSTWA W POLSCE}

\section{THE INFLUENCE OF DEMOGRAPHIC CHANGES ON THE ECONOMIC SAFETY OF THE OLD AGE OF SOCIETY IN POLAND}

DOI: $10.15611 /$ sie.2015.1.03

JEL Classification: H55 i J11.

Streszczenie: Celem artykułu jest omówienie konsekwencji gospodarczych, jakie niesie za sobą fakt starzenia się polskiego społeczeństwa. W artykule akcentowane są negatywne skutki starzenia, które przekładają się na wzrost wydatków publicznych. Egzemplifikacją starzenia są dynamiczne zmiany struktury społecznej pod względem wieku, a szczególnie wzrost liczebności kohorty w wieku poprodukcyjnym. Zaistniała sytuacja ma wpływ na stabilność finansów publicznych ze względu na konieczność zwiększenia wydatków publicznych na zabezpieczenia społeczne i zdrowotne. W tekście artykułu wyjaśniono również pozytywne aspekty starzenia się społeczeństwa dla polskiej gospodarki, które są impulsem do rozwoju nowych segmentów rynku dóbr i usług związanych ze wzrostem konsumpcji osób starszych. Nowe wyzwania i możliwości otwiera tzw. srebrna gospodarka.

Slowa kluczowe: rodzina, starzenie się, system emerytalny, opieka zdrowotna, „,srebrna gospodarka".

Summary: The aim of this article is to discuss the economic consequences brought about by the ageing of the Polish society. The article emphasises the negative effects of ageing which translates into growing public expenditure. The population ageing is exemplified by the dynamic age-related changes of the social structure, and in particular by the growing numbers of the retirement age cohort. The present situation affects the stability of the public finances as it necessitates an increase in the public expenditure on social security and health care. The article also explains the positive aspects of population ageing for the Polish economy, which acts as an impulse for the growth of the new segments of goods and services market linked to the growing consumption by the elderly population. New challenges and opportunities are created by the so-called "silver economy".

Keywords: family, ageing, pension system, health care, "silver economy". 


\section{Wstęp}

Transformacja demograficzna powoduje niekorzystną z perspektywy finansów publicznych zamianę. Ubywa osób młodych, „tańszych w utrzymaniu”, a przybywa osób starszych, „droższych w utrzymaniu” (generujących wyższe wydatki). Oczywistą konsekwencją takiej zmiany jest wzrost ogólnego poziomu wydatków publicznych, co określane jest mianem „siwienia budżetów publicznych"1. Największy udział w wydatkach publicznych stanowią wydatki socjalne, czyli między innymi wydatki finansujące emerytury, renty i opiekę zdrowotna.

Polskie społeczeństwo doświadcza transformacji demograficznej. Na skutek zmiany modelu rodziny przybywa osób po 65 roku życia, a niska liczba urodzeń (tab. 2) nie gwarantuje prostej zastępowalności pokoleń. Dla zapewnienia stabilności finansów publicznych przeprowadzono w roku 1999 reformę systemu emerytalnego.

W związku z tym, że w perspektywie 20 lat nadal będzie wzrastać liczba osób w wieku 65 lat (rys. 6), zdecydowano również o podwyższeniu i zrównaniu wieku emerytalnego kobiet i mężczyzn.

Celem artykułu jest konceptualizacja konsekwencji gospodarczych starzenia się społeczeństwa polskiego w kontekście stabilności finansów publicznych.

\section{Atrofia rodziny tradycyjnej}

Świat, w którym żyjemy, został w sensie instytucjonalnym w znacznym stopniu ukształtowany w XIX wieku, czego egzemplifikacją są funkcjonujące społeczne podsystemy funkcjonalne, a szczególnie system emerytalny oparty na solidarności międzypokoleniowej.

Podstawą tego podsystemu była tradycyjna, patriarchalna, wielopokoleniowa rodzina. Wszyscy jej członkowie musieli pracować - by przeżyć. Jak to określił A. Toffler, rodzina tego typu stanowiła połączenie brygady produkcyjnej, szkoły, szpitala polowego, żłobka i domu starców². Rodzina była więc koniecznością, a poza rodziną nie można było funkcjonować. Była ona zdominowana kulturowo, a cele rodziny i sposoby ich osiagania wyznaczały religia, obyczaj i tradycja, a nie system ekonomiczny wraz ze swoim medium, czyli pieniądzem. Państwo i społeczno-ekonomiczne podsystemy funkcjonalne nie odgrywały żadnej roli, dlatego dzieci reprezentowały ducha polityki ubezpieczeniowej, zapobiegając ubóstwu rodziców w okresie starości. Niski poziom opieki zdrowotnej sprawiał, że wysokie wskaźniki dzietności szły w parze z wysoką śmiertelnością niemowląt i dzieci³

${ }^{1}$ Ł. Jurek, Ekonomia starzejacego się społeczeństwa, Difin, Warszawa 2012, s. 78-79.

2 A. Toffler, Trzecia fala, PIW, Warszawa 1985, s. 272.

${ }^{3}$ W. Tyc, Ekonomiczne i społeczne uwarunkowania transformacji rodziny, Wydawnictwo Akademii Ekonomicznej im. Oskara Langego we Wrocławiu, Wrocław 2007, s. 128-129. 
Opieka nad dziećmi nie kolidowała z pracą w gospodarstwie ze względu na strukturę rodziny, specyfikę życia „,pod jednym dachem” oraz indywidualnie regulowany czas pracy. Dlatego koszt alternatywny wychowania dzieci był stosunkowo niski, podobnie jak koszt wyżywienia, ubrań itp., co przekładało się na niskie koszty krańcowe dziecka4 ${ }^{4}$.

Rozwój gospodarki towarowo-pieniężnej i wymiany, czyli systemu ekonomicznego, był impulsem dla przeobrażeń rodziny. Nastapił podział działalności gospodarczej rodziny na pracę $\mathrm{w}$ gospodarstwie i pracę zarobkową, a jej celem stał się dochód pieniężny. Zasadniczej zmianie uległa rola kobiety. Kobieta, niegdyś „strażniczka ogniska domowego" i pozbawiona praw, dzięki równouprawnieniu odzyskała niezależność. Możliwość podjęcia pracy zarobkowej oznaczała jej samodzielność finansowa. W konsekwencji mężczyzna przestał być jedynym żywicielem rodziny, a rodzina dzięki pracy obojga rodziców mogła się bogacić i zaspokajać więcej potrzeb. Konieczność pogodzenia roli kobiety w rodzinie i jej zawodowych aspiracji doprowadziły do zmian zachowań prokreacyjnych, a w konsekwencji do zmniejszenia liczby dzieci w rodzinie.

\section{Zjawisko starzenia się społeczeństwa}

Starzenie się społeczeństw to zjawisko, które dotyka wszystkich krajów Unii Europejskiej, w tym również Polski. Jeśli cofniemy się pamięcią, to zaobserwujemy, że dzisiejsza sytuacja demograficzna Polski oraz krajów rozwiniętych jest znacząco różna od tej sprzed kilku dziesięcioleci. Lata 60. i 70. XX wieku przyniosły tzw. baby boom, który był naturalną konsekwencją odbudowy populacji po II wojnie światowej. Następnie zaczęto obawiać się tego nadzwyczajnego przyrostu naturalnego, widząc w nim zagrożenie nadmiernego przeludnienia. Po pięćdziesięciu latach odnotowuje się procesy odwrotne do tych z lat 60. i 70. XX wieku, a mianowicie przede wszystkim spadek dzietności i wydłużenie okresu trwania życia.

Postęp cywilizacyjny, rozwój medycyny, profilaktyki zdrowotnej i higieny oraz „prolongata młodości” związana z realizacją aspiracji edukacyjnych osób starszych determinuje układ pokoleniowy społeczeństwa, w którym ubywa dzieci, rośnie natomiast kohorta osób w wieku poprodukcyjnym ${ }^{5}$.

W demografii dla opisu długoterminowych procesów ludnościowych przyjmuje się za podstawowy (choć z wieloma modyfikacjami) trójfazowy model cyklu demograficznego, który ilustruje etapy przejścia demograficznego oraz konfiguracje zachowań demograficznych (tab. 1$)^{6}$.

${ }^{4}$ Tamże, s. 130.

${ }^{5}$ R.J. Kijak, Z. Szarota, Starość. Między diagnozq a działaniem, Centrum Rozwoju Zasobów Ludzkich, Warszawa 2013, s. 6.

${ }^{6}$ A. Giza, M. Sikorska, Wspótczesne społeczeństwo polskie, Wydawnictwo Naukowe PWN, Warszawa 2012, s. 23. 
Tabela 1. Konfiguracje zachowań demograficznych według trójfazowego modelu cyklu demograficznego

\begin{tabular}{|l|l|}
\hline \multicolumn{1}{|c|}{ Konfiguracje } & \multicolumn{1}{c|}{ Charakterystyka zachowań } \\
\hline 1. konfiguracja & Wysoka stopa urodzeń oraz wysoka stopa zgonów \\
\hline 2. konfiguracja & Wysoka stopa urodzeń oraz obniżająca się stopa zgonów \\
\hline 3. konfiguracja & Niska stopa urodzeń oraz niska stopa zgonów \\
\hline
\end{tabular}

Źródło: opracowanie własne.

Konsekwencją pierwszej konfiguracji jest stagnacja, która może być charakterystyczna dla społeczności rolniczych. Druga konfiguracja wywołuje gwałtowny wzrost populacji industrialnych, kojarzona jest z pojawieniem się innowacji w rolnictwie, rozwojem medycyny, poprawą warunków sanitarnych. Ostatnia, trzecia konfiguracja to obraz charakterystyczny dla starzejącego się postindustrialnego społeczeństwa z trendem spadkowym liczebności populacji.

Wyniki analizy wieku społeczeństwa przedstawia się najczęściej w postaci tzw. piramidy wieku. Jej naturalny ksztalt - trójkąt o szerokiej podstawie, przedstawia populację progresywną czyli młodą, w której rośnie liczba urodzeń. Kształt nienaturalnego wybrzuszania się piramidy w części środkowej aż do górnej z jednoczesnym zwężeniem podstawy jest oznaką populacji regresywnej, która cechuje się małym wskaźnikiem urodzeń i wysoką przeciętną długością życia. Opis tego wykresu jest zgodny ze stosowaną w demografii definicją, która mówi, że starzenie się ludności oznacza zwiększanie odsetka osób starszych z jednoczesnym zmniejszaniem odsetka dzieci .

Dane zawarte w tab. 2 obrazują zmiany demograficzne w Polsce w ciągu 33 lat.

Tabela 2. Podstawowe dane demograficzne, lata 1980-2013

\begin{tabular}{|c|c|c|c|c|c|c|c|c|}
\hline Rok & $\begin{array}{c}\text { Liczba } \\
\text { ludności } \\
\text { (w tys.) }\end{array}$ & $\begin{array}{c}\text { Urodzenia } \\
\text { żywe } \\
\text { (w tys.) }\end{array}$ & $\begin{array}{c}\text { Zgony } \\
\text { (w tys.) }\end{array}$ & $\begin{array}{c}\text { Przyrost } \\
\text { naturalny } \\
\text { (w tys.) }\end{array}$ & $\begin{array}{c}\text { Liczba dzieci na } \\
\text { jedną kobietę } \\
\text { w wieku } \\
\text { reprodukcyjnym }\end{array}$ & $\begin{array}{c}\text { Ludność } \\
\text { wieku przed- } \\
\text { produkcyjnym } \\
\text { (w \%) }\end{array}$ & $\begin{array}{c}\text { Ludność } \\
\text { w wieku } \\
\text { produk- } \\
\text { cyjnym } \\
\text { (w \%) }\end{array}$ & $\begin{array}{c}\text { Ludność } \\
\text { wieku } \\
\text { ponad } \\
65 \text { lat } \\
\text { (w) }\end{array}$ \\
\hline 1980 & 35735 & 695,8 & 353,2 & 342,6 & 2,28 & 28,8 & 59,4 & 11,8 \\
\hline 1990 & 38073 & 547,7 & 390,3 & 157,4 & 1,99 & 29 & 58,2 & 12,8 \\
\hline 2000 & 38254 & 378,3 & 368,0 & 10,3 & 1,22 & 24,4 & 60,8 & 14,8 \\
\hline 2010 & 38530 & 413,3 & 378,5 & 34,8 & 1,38 & 18,8 & 64,4 & 16,8 \\
\hline 2011 & 38538 & 388,4 & 375,5 & 12,9 & 1,30 & 18,5 & 64,2 & 17,3 \\
\hline 2012 & 38533 & 386,2 & 384,8 & 1,40 & 1,29 & 18,3 & 63,8 & 17,9 \\
\hline 2013 & 38496 & 369,6 & 387,3 & $-17,7$ & 1,25 & 18,3 & 63,4 & 18,3 \\
\hline
\end{tabular}

Źródło: opracowanie własne na podstawie danych GUS, Rocznik demograficzny 2013, [http://www. stat.gov.pl].

7 W literaturze za metrykalny próg starości przyjmuje się wiek 60 lat lub - coraz częściej - 65 lat. W niniejszym opracowaniu osoby w starszym wieku to ludność w wieku 65 lat i więcej. 
W latach 1980-1990 dynamicznie wzrosła liczba ludności - z niespełna 36 do 38 mln obywateli - i do dziś nie przekroczyła granicy 39 mln osób. Poziom urodzeń żywych ulegał wyraźnemu spadkowi, co przy wzroście liczby zgonów wpłynęło na ogromny spadek przyrostu naturalnego. Przyrost naturalny (różnica pomiędzy liczbą narodzin i zgonów), który w 1980 r. wynosił 342600 osób, spadł do poziomu 1400 osób w 2012 r., a w roku 2013 osiagnął wartość ujemną. Jeszcze rok 1980 zapewniał naturalną zastępowalność pokoleń, gdyż wskaźnik dzietności wynosił 2,28. Wskaźnik ten obniżył się do wartości 1,25 w roku 2013. Udział ludności w wieku przedprodukcyjnym zmniejszył się z 28,8 \% do 18,3\%, ludność w wieku produkcyjnym zwiększyła się z 59,4\% do 63,4\%, a najbardziej wzrósł odsetek ludności $\mathrm{w}$ wieku poprodukcyjnym, czyli w wieku ponad 65 lat z $11,8 \%$ do $18,3 \%$.

Godny podkreślenia jest fakt zrównania się w roku 2013 obciążenia ludności w wieku aktywności zawodowej ludnością w wieku przed- i poprodukcyjnym. Po roku 2013 większe będzie ekonomiczne brzemię starości niż ciężary związane z zapewnieniem wychowania dzieci i młodzieży ${ }^{8}$.

Dane zawarte $\mathrm{w}$ tab. 2 potwierdzają ogólny pogląd o starzeniu się polskiego społeczeństwa. Starzenie się społeczeństw, mimo iż może - i prawdopodobnie powinno - być postrzegane jako sukces ludzkości, jest kosztowne. Wiąże się z potrzebą między innymi reorganizacji opieki medycznej i systemów emerytalnych?

\section{Wplyw starzenia na system emerytalny}

Zmiany wiekowej struktury ludności Polski przynoszą wzrost obciążenia demograficznego osobami w wieku poprodukcyjnym (tab. 2), co przekłada się na zagrożenie systemu emerytalnego opartego na zasadzie „solidarności pokoleniowej”. Przez „obciążenie demograficzne" rozumie się liczbę osób niepracujących przypadających na jedną pracująca. Do osób niepracujących zaliczamy osoby młode, np. uczące się, oraz osoby, które osiagnęły wiek emerytalny. W związku z tym rozróżnia się obciążenie demograficzne osobami w wieku przedprodukcyjnym i osobami w wieku poprodukcyjnym. Według prognoz długoterminowych spodziewany jest wzrost osób w wieku poprodukcyjnym w ogólnej liczbie osób.

Jak wynika z rys. 1, poziom populacji (suma grup wiekowych w roku) jest mniejszy w każdym roku. W ciągu 40 lat zmaleje liczba osób w wieku przedprodukcyjnym - z niespełna $7 \mathrm{mln}$ do 4,4 mln w roku 2060. W grupie wieku produkcyjnego istnieje taki sam trend spadkowy, natomiast liczba osób w wieku poprodukcyjnym wzrasta z około 7,3 mln w roku 2020 do 9,6 mln w roku 2060.

Współcześni badacze światowi i polscy dowiedli, że to właśnie obciążenie demograficzne osobami $\mathrm{w}$ wieku poprodukcyjnym jest szczególnie obciążające dla

${ }^{8}$ P. Szukalski, Starzenie się ludności a publiczny kontrakt intergeneracyjny, http://dspace.uni. lodz.pl:8080 /xmlui/handle/11089/4096 (10.01.2015).

${ }^{9}$ A. Giza, M. Sikorska, wyd. cyt., s. 32. 


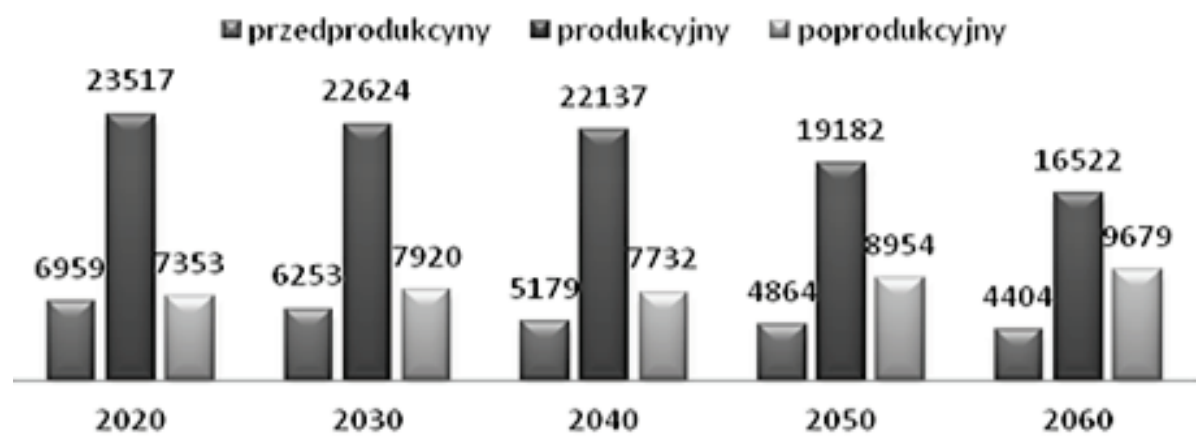

Rys. 1. Prognoza populacji Polski w podziale na ekonomiczne grupy wieku (w tysiącach); stan na koniec roku

Źródło: opracowanie własne na podstawie danych GUS, Sytuacja demograficzna osób starszych $i$ konsekwencje starzenia się ludności Polski w świetle prognozy na lata 2014-2050, [http://www. stat.gov.pl].

gospodarki, w tym dla systemu emerytalnego, gdyż bezpośrednio obciąża osoby aktywne zawodowo, których składki finansują bieżące emerytury.

Steven A. Nyce i Sylvester J. Schieber, analizując łączne współczynniki obciążeń demograficznych 10 krajów (Australii, Belgii, Czech, Danii, Holandii, Norwegii, Nowej Zelandii, USA, Szwecji i Wielkiej Brytanii ${ }^{10}$ ), potwierdzili, że w badanych krajach wydatki publiczne na osoby starsze były wyraźnie wyższe niż na młodzież. Udowodnili, że większa część konsumpcji osób starszych jest finansowana z programów emerytalnych, podczas gdy konsumpcja młodzieży jest w znacznym stopniu finansowana z prywatnych transferów od rodziców ${ }^{11}$.

W latach 2000 i 2008 również w Polsce analizowano poziom wydatków przypadających na jednego ucznia i emeryta (rys. 2). Z wyliczeń wynika, że w każdym kolejnym badanym roku wydatki na jednego emeryta przewyższały wydatki na jednego ucznia. I choć różnica wydatków w roku 2008 była najmniejsza, to i tak wartość wydatków na emeryta wyniosła około 18 tys. zł, podczas gdy na jednego ucznia około 11 tys. zł.

Ludzie starsi są dla budżetu państwa większym obciążeniem ekonomicznym niż osoby młode. Konsumują oni większy zakres świadczeń społecznych, a ponadto świadczenia te są bardziej kosztowne ${ }^{12}$.

${ }^{10}$ Kraje, w których udało się zgromadzić pełne dane dotyczące wydatków na publiczne finansowanie emerytur, opiekę zdrowotną nad osobami starszymi, a także dane na temat wysokości świadczeń na dzieci i rodziny, łącznie z edukacją.

11 S.A. Nyce, S.J. Schieber, Ekonomiczne konsekwencje starzenia się społeczeństw, Wydawnictwo Naukowe PWN, Warszawa 2011, s. 79-82.

12 Ł. Jurek, Ekonomia starzejacego..., s. 78. 


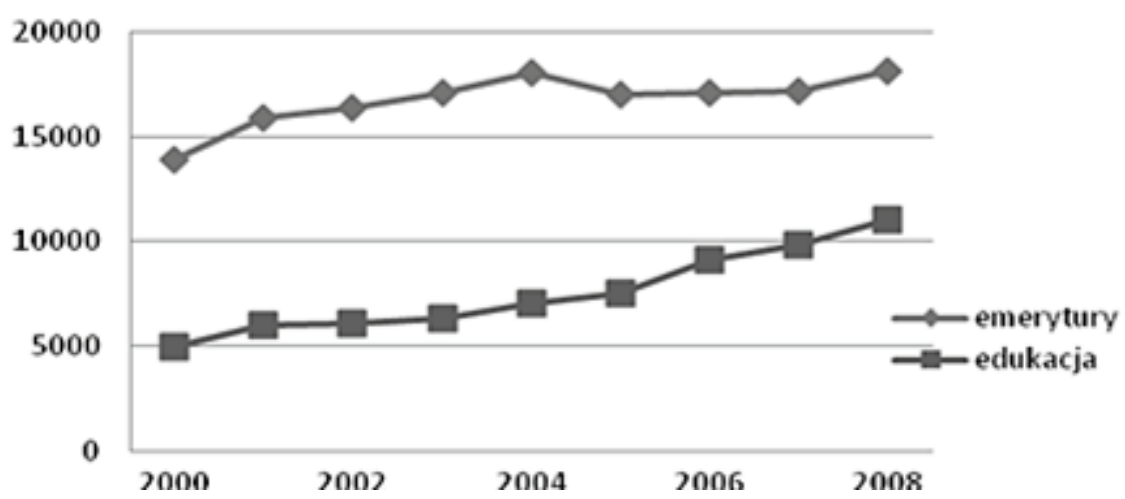

Rys. 2. Wydatki na edukację i emerytury w przeliczeniu na 1 ucznia i 1 emeryta w złotych - Polska 2000-2008

Źródło: opracowanie własne na postawie: P. Szukalski, Solidarność pokoleń. Dylematy relacji międzypokoleniowych, Wydawnictwo Uniwersytetu Łódzkiego, Łódź 2012, s. 197.

Ludzie starsi, przechodząc na emeryturę, kończą swój okres aktywności zawodowej. Pracując, zarabiali i płacili podatki, aktualnie będą się utrzymywać ze świadczeń społecznych. Wobec demograficznego starzenia społeczeństwa sytuacja ta powoduje, że wyraźnie maleją wpływy do budżetu z podatków, rosną natomiast wydatki publiczne.

Największy udział w wydatkach publicznych stanowią wydatki socjalne. Według Raportu Racjonalizacji Wydatków Społecznych „Zielona Księga”, opracowanego przez Ministerstwo Gospodarki, Pracy i Polityki Społecznej w październiku 2003 roku, wydatki socjalne od roku 1990 do roku 2002 stanowiły odpowiednio $24,7 \%$ i $40,9 \%$ udziału w wydatkach publicznych.

Dane zawarte w tab. 3 potwierdzają, że największy udział w wydatkach socjalnych państwa w roku 2014 stanowiły emerytury i renty $-52,4 \%$, oraz wydatki na opiekę zdrowotną - odpowiednio $25,1 \%$. W kolejnych latach prognozowany jest systematyczny, choć powolny wzrost tych wydatków. Jest on nierozerwalnie związany ze starzeniem się społeczeństwa, czyli z coraz większym odsetkiem osób osiągających wiek emerytalny, ale również osób schorowanych i niepełnosprawnych. Osoby te generować będą coraz większe obciążenie dla budżetu państwa.

Koszt świadczeń socjalnych powinien być na bieżąco pokrywany dochodami $\mathrm{z}$ danin publicznych (np. łączna wartość wypłaconych emerytur powinna być równa łącznym wpływom ze składek emerytalnych). Jednak w starzejącym się społeczeństwie wydatki rosną tak szybko, że utracona zostaje zdolność finansowania ich z podatków i składek. Dlatego koniecznością staje się wykorzystanie długu publicznego ${ }^{13}$.

\footnotetext{
${ }^{13}$ Ł. Jurek, Ekonomia starzejacego..., s. 84.
} 
Tabela 3. Struktura wydatków socjalnych 2014-2020 (w \%)

\begin{tabular}{|l|c|c|c|c|}
\hline \multicolumn{1}{|c|}{ Wyszczególnienie } & 2014 & 2016 & 2018 & 2020 \\
\hline Wydatki socjalne ogólem & $\mathbf{1 0 0}$ & $\mathbf{1 0 0}$ & $\mathbf{1 0 0}$ & $\mathbf{1 0 0}$ \\
\hline Emerytury i renty & 52,4 & 52,6 & 53,1 & 53,8 \\
\hline Emerytury & 32,0 & 32,9 & 34,2 & 35,6 \\
\hline Renty z tytułu niezdolności do pracy & 11,7 & 11,4 & 11,0 & 10,7 \\
\hline Renty rodzinne & 8,6 & 8,3 & 7,9 & 7,6 \\
\hline Wydatki na bezrobocie & 4,5 & 4,4 & 4,3 & 4,2 \\
\hline Opieka zdrowotna & 25,1 & 25,3 & 25,3 & 25,4 \\
\hline Pomoc społeczna & 2,6 & 2,3 & 2,1 & 1,9 \\
\hline Świadczenia rodzinne & 4,5 & 4,3 & 4,1 & 3,9 \\
\hline Zasiłki krótkookresowe & 4,4 & 4,5 & 4,5 & 4,5 \\
\hline Koszty administracji i pozostałe & 3,7 & 3,7 & 3,8 & 3,4 \\
\hline Inne wydatki socjalne & 2,8 & 2,8 & 2,8 & 2,8 \\
\hline
\end{tabular}

Źródło: opracowanie własne na podstawie danych zawartych w Projekcji wydatków socjalnych na lata 2004-2020 [http://www.funduszestrukturalne.gov.pl/informator/npr2/prognozy/Projekcja\%20 wydatkow\%20socjalnych\%20w\%20latach\%202004-2020\%20\%28MPS\%29.pdf].

Dług publiczny to nominalne zadłużenie podmiotów sektora finansów publicznych, utworzone przez skumulowane deficyty budżetu państwa, budżetów jednostek samorządu terytorialnego oraz innych podmiotów zależnych od sektora finansów publicznych. Dług publiczny oraz daniny publiczne są składowymi wydatków publicznych.

Obok długu publicznego istnieje w literaturze również określenie długu emerytalnego.

Według Dariusza Stańki stary system emerytalny oparty na zasadzie repartycyjnej, następnie zreformowany w 1999 r. poprzez wprowadzenie formy kapitałowej, był przyczyną powstania długu emerytalnego. Jak wynika z rys. 3, dług emerytalny składa się z trzech części: demograficznej, politycznej i emerytalnej.

Za część demograficzną długu odpowiada obciążenie systemu emerytalnego w taki sposób, że coraz więcej osób starszych jest na utrzymaniu malejącej liczby młodych osób. Dlatego ten przypadek dyskwalifikuje samodzielne istnienie systemu repartycyjnego, który naturalnie staje się niewydolny. I to jest zarazem jego wymiar obiektywny - ściśle związany z demografią. Natomiast postać subiektywna wynika $\mathrm{z}$ działania grup interesu. Rezultatem tego działania są liczne przywileje emerytalne, finansowane przez pozostałych podatników.

Polityczna część długu jest konsekwencją między innymi obniżenia składki rentowej, która zwiększyła deficyt Funduszu Ubezpieczeń Społecznych, odraczania w czasie likwidacji wcześniejszych emerytur (aż do końca 2009 r.), braku działań reformatorskich w Kasie Rolniczego Ubezpieczenia Społecznego. 


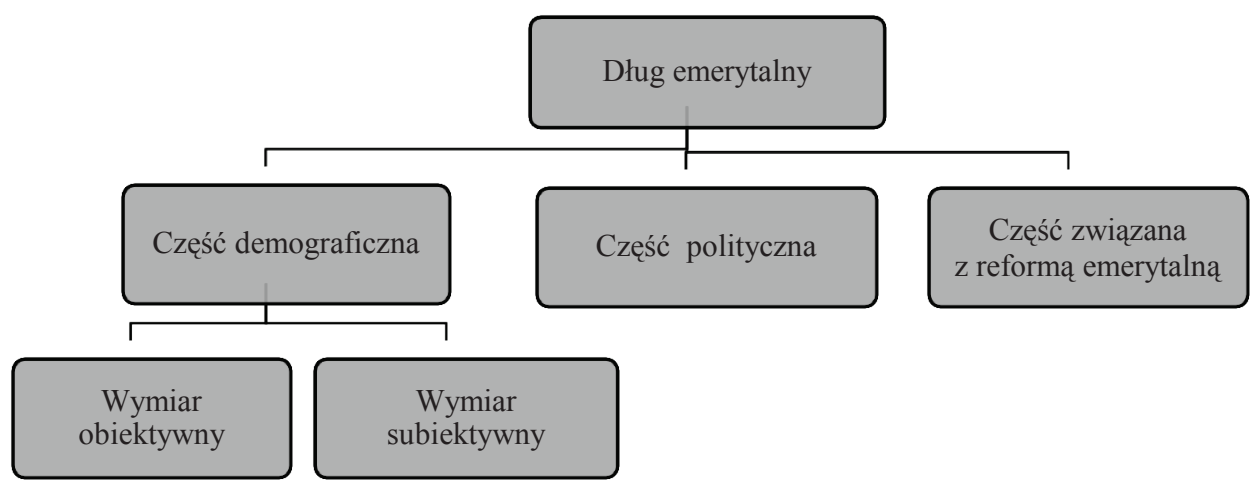

Rys. 3. Struktura długu emerytalnego

Źródło: opracowanie własne.

Trzecim elementem długu jest obciążenie finansowe budżetu związane z wprowadzeniem systemu kapitałowego, ponieważ część składki emerytalnej zaczęła zasilać konta emerytalne w Otwartych Funduszach Emerytalnych (II filar), co spowodowało odpływ środków z Funduszu Ubezpieczeń Społecznych. Dlatego system kapitałowy może odpowiadać za pogorszenie sytuacji finansowej budżetu w sposób przejściowy, do momentu zakończenia finansowania kohort otrzymujących emerytury ze starego systemu ${ }^{14}$.

System emerytalny jest ważnym składnikiem struktury instytucjonalnej, w której funkcjonuje społeczeństwo. Reforma systemu przeprowadzona w 1999 roku była odpowiedzią na zachodzące zmiany demograficzne. Jej celem było zmodernizowanie systemu niedopasowanego do aktualnej rzeczywistości. Jednak sytuacja gospodarcza wymusza kolejne zmiany, czego odzwierciedleniem jest wydłużenie i zrównanie wieku emerytalnego kobiet i mężczyzn, gdyż ma to wpływ na stabilność systemu emerytalnego w długim okresie.

\section{Wpływ starzenia na zabezpieczenie zdrowotne}

Wydłużanie się okresu trwania życia daje możliwość doczekania sędziwej starości. Dla państwa oznacza to wzrost zapotrzebowania tej grupy ludności na bieżącą opiekę zdrowotną i dhugoterminowe usługi opiekuńcze. W tradycyjnym modelu rodziny rodzice otrzymywali opiekę od swych dzieci, aktualnie zaś zmieniona struktura rodziny wskutek niskiej dzietności już tego w pełni nie gwarantuje. Funkcje opieki docelowo będzie musiało przejąć na swe barki państwo. A wizja przyszłości nie rysuje się nazbyt optymistycznie.

${ }^{14}$ D. Stańko, Wpływ systemu emerytalnego na gospodarke, http://www.inepan.waw.pl/pliki/studia _ekonomiczne/ stanko.pdf (05.01.2015). 
R. Hammond, popularny brytyjski futurysta, w swej książce The World in 2030, wydanej w 2007 roku, przedstawił swą wizję świata w 2030 roku. Przewiduje on, że w niedalekiej przyszłości na skutek rozwoju technologii medycznej znacznie wydłuży się trwanie życia. Obecnie średnia długość życia wydłuża się przeciętnie o 3 miesiące w skali roku. Oznacza to, że w ciagu ostatnich stu lat do trwania ludzkiego życia zostało dodane ponad ćwierć wieku. Za sprawą modyfikacji genetycznych oraz rozwoju medycyny odmładzającej i antystarzeniowej w przyszłości możliwe będzie osiągnięcie wydłużenia średniej długości życia o jeden rok w ciągu roku. Statystycznie oznacza to, że osoba, która przeżyje jeden rok, dostanie dodatkowy jeden rok życia poniekąd „gratis”. Taki stan rzeczy spowoduje wzrost zapotrzebowania na opiekę świadczoną przez wyspecjalizowane podmioty publiczne i prywatne. Podstawowe problemy w tym zakresie to zapewnienie dostępności i wysokiej jakości świadczeń, a także stabilności finansowej i racjonalności systemu wsparcia osób chorych i niesamodzielnych ${ }^{15}$.

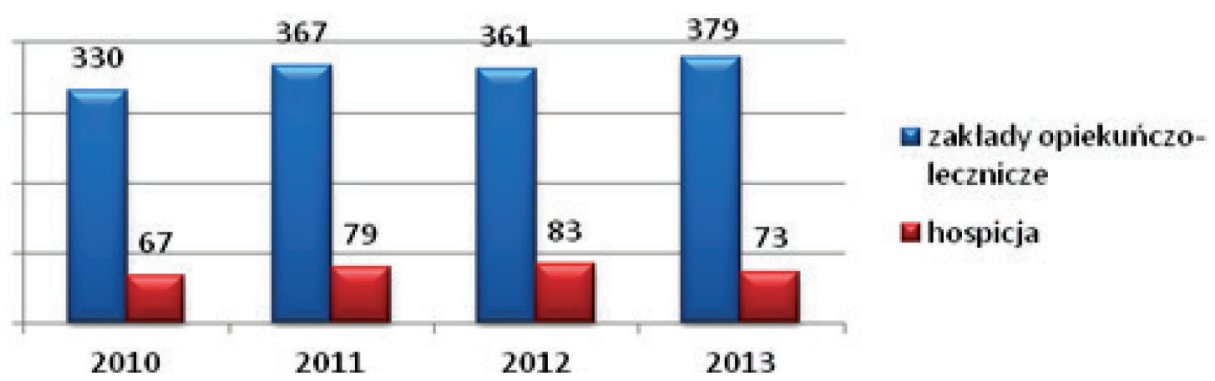

Rys. 4. Liczba placówek zakładów opiekuńczo-leczniczych i hospicjów w Polsce

Źródło: opracowanie własne na podstawie: GUS, Bank Danych Lokalnych, [http://stat.gov.pl/bdl/app/ strona.html?p_name=indeks].

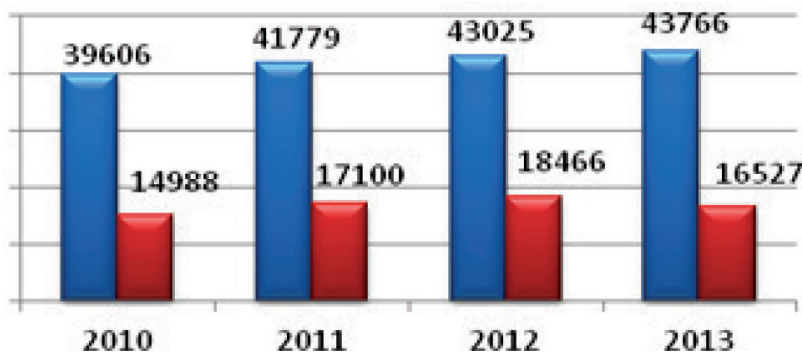

回pacjenci zakladów opiekunczo-leczniczych

国pacjencihospicjów

Rys. 5. Liczba pacjentów zakładów opiekuńczo-leczniczych i hospicjów w Polsce

Źródło: opracowanie własne na podstawie: GUS, Bank Danych Lokalnych [http://stat.gov.pl/bdl/app/ strona.html?p_name=indeks].

${ }^{15}$ Ł. Jurek, Proces demograficznego starzenia jako istotne wyzwanie dla spoleczeństwa polskiego w XXI wieku, [w:] Kowalczyk O. (red.), Nauki społeczne. Współczesne społeczeństwa - nadzieje i zagrożenia, Wydawnictwo Uniwersytetu Ekonomicznego we Wrocławiu, Wrocław 2010, s. 70-72. 
Z danych Głównego Urzędu Statystycznego wynika, że w Polsce rośnie liczba zakładów opiekuńczo-leczniczych (rys. 4). Od roku 2010 do roku 2013 odnotowano ich wzrost z 330 do 379 .

Zwiększyła się też liczba hospicjów - z 67 w roku 2010 do 83 w roku 2012, $\mathrm{z}$ małym spadkiem w roku 2013. Wzrost liczby tych instytucji wynika z zapotrzebowania społecznego. Natomiast dane, które ilustruje rys. 5, potwierdzają, że z roku na rok rośnie liczba pacjentów obsługiwanych przez hospicja.

Wszystko wskazuje na to, że współcześni dorośli (a tym bardziej dzieci) mają szanse na długowieczność mniej obciążoną chorobami z zachowaną sprawnością i samodzielnością funkcjonowania, co może przyczynić się do zwiększonej aktywności osób starszych i przejmowania bardziej wyrafinowanych wzorów konsumpcji i stylu życia ${ }^{16}$.

\section{Silver economy}

Z danych prognozowanych Głównego Urzędu Statystycznego (rys. 6) wynika, że po 2025 roku udział osób w wieku powyżej 65 lat w ogólnej liczbie ludności przekroczy granicę $21 \%$ i będzie nadal wzrastał aż do poziomu 32,7\% w roku 2050. Przebieg zmian liczebności osób powyżej 65 roku życia pokrywa się z występowaniem wyżów i niżów urodzeń w II połowie ubiegłego stulecia. I choć prognozy nastrajają pesymistycznie - zapowiadając możliwą niewydolność finansów publicznych związaną z wydłużaniem dalszego trwania życia, to zaistniała sytuacja ekonomiczna może spowodować zagospodarowanie niszy rynkowej związanej z przyszłą, zwiększoną konsumpcją starszego pokolenia.

W opinii Guillaume Wunscha starzenie się może mieć pozytywny wpływ na gospodarkę, pobudzając rozwój nowych produktów i usług lepiej dostosowanych do

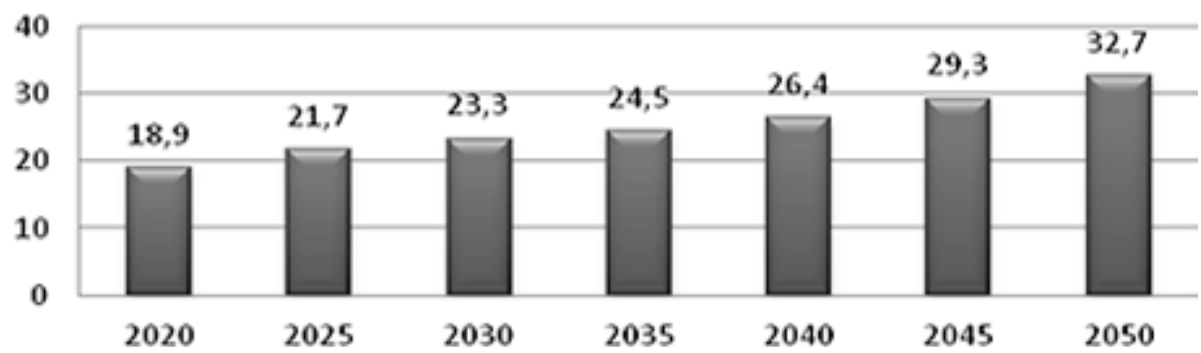

Rys. 6. Udział procentowy ludności w wieku 65 lat i więcej w ogólnej liczbie ludności (w \%)

Źródło: opracowanie własne na podstawie danych GUS: Sytuacja demograficzna osób starszych i konsekwencje starzenia się ludności Polski w świetle prognozy na lata 2014-2050, [http://www. stat.gov.pl/].

${ }^{16}$ R.J. Kijak, Z. Szarota, wyd. cyt., s. 12. 
potrzeb starszych osób. Nowe wyzwania i możliwości tworzy tzw. srebrna gospodarka (silver economy) ${ }^{17}$, czyli strategia ekonomiczna, generująca usługi skierowane do starszych wiekiem obywateli ${ }^{18}$. Jej rozwój niesie określone wyzwania, konieczności, konsekwencje dla konsumenckiego rynku i gospodarki opartej na usługach.

W srebrnej gospodarce ludzie starsi traktowani są jako aktywna, produktywna i przydatna społecznie grupa. Należy korzystać z kapitału doświadczenia starszych wiekiem pracowników. Trzeba wspierać rodzinne przedsiębiorstwa, w których często wykorzystywana jest aktywność seniorów. Silver economy łączy interesy producentów i biznesu z sektorem opieki nad seniorami. Przykładem mogą być telemedycyna, teleopieka, firmy świadczące usługi opiekuńcze i pielęgnacyjne, domy opieki. Proces starzenia się wpływa na rozwój nowych segmentów rynku usług, takich jak: rynek produktów i usług kosmetycznych, medycyny estetycznej, turystyki o charakterze pielgrzymkowym itp. ${ }^{19}$

Bezwzględnie należy przygotować jednostki i społeczeństwo do zmierzenia się z niespotykanymi dotąd rozmiarami obecności seniorów na rynku pracy i w roli konsumentów.

W Polsce dotychczasowy stereotyp starszej osoby oparty na tradycyjnym jej postrzeganiu jako biednej, schorowanej, skupionej jedynie na zaspokajaniu życiowych potrzeb stopniowo ulega zmianie. Niektórzy starsi ludzie dysponują coraz większym dochodem rozporządzalnym, stając się grupą konsumentów o rosnących możliwościach $^{20}$.

\section{Zakończenie}

W artykule omówiono wybrane konsekwencje starzenia się społeczeństwa polskiego - o charakterze kulturowym i ekonomicznym oraz pod kątem ich wpływu na dochody i wydatki publiczne.

Dynamika starzenia się społeczeństwa znajduje swoją przyczynę w transformacji rodziny, głównie w jej zmniejszeniu i trwałości. Posiadanie dzieci jest kosztowne. Również konsumpcyjne i hedonistyczne podejście do życia powoduje, że obecnie najczęstszy model rodziny to „2 $2+1$ " lub rodzina bezdzietna. Dzisiejszą rodzinę określić można najkrócej jako małą, jednopokoleniową, miejską, z możliwym luźnym związkiem rodziców, konsumpcyjną, inwestującą w ,jakość” dzieci.

Rozwój społeczno-ekonomicznych podsystemów funkcjonalnych sprawil, że znika konieczność utrzymania solidarności międzypokoleniowej. Rodzina staje się dla przedsiębiorczej jednostki zbędnym balastem i źródłem ryzyka i niepewności.

17 Tamże, s. 30.

18 W marketingu kategoria „starszy konsument” obejmuje osoby w wieku powyżej 50 lat.

19 Tamże, s. 30-32.

20 F. Bylok, Zachowania konsumpcyjne seniorów na rynku dóbr i ustug, [w:] Kałuża-Kopias D., Szukalski P. (red.), Starzenie się ludności - między demografia a polityka społecznq, Wydawnictwo Uniwersytetu Łódzkiego, Łódź 2013, s. 140. 
Stąd racjonalniej ekonomicznie jest zapłacić składkę ubezpieczeniową będącą zabezpieczeniem w razie choroby czy starości, niż wychowywać dzieci ${ }^{21}$.

Negatywnym skutkiem transformacji rodziny jest również to, że ludzie starzeją się samotnie. Brak najbliższych oraz posiadane środki finansowe pozwalają na zamieszkiwanie w domach spokojnej starości. Jest to sposób na dożycie, jednak nie zastapi on rodziny.

Transformacja demograficzna w większym stopniu wpływa na wydatki niż dochody publiczne. Ma to odzwierciedlenie we wzroście wydatków socjalnych, których zasadniczym elementem są emerytury i renty oraz wydatki związane z opieką zdrowotną. Coraz większy przyrost ludności w wieku powyżej 65 lat oraz wydłużony okres ich trwania życia „wyceniają” ludzi starszych jako bardziej „kosztownych” w utrzymaniu niż ludzi młodych. Stan ten bezpośrednio implikuje dłuższy okres pobierania emerytur oraz większe wydatki zdrowotne - będące konsekwencją pogarszającego się stanu zdrowia.

Zaistniała sytuacja w przyszłości najprawdopodobniej wymusi przesunięcia w budżecie państwa. Wyższe wydatki na emerytury, renty, opiekę zdrowotną pociągną za sobą konieczność ograniczania innych wydatków. Może to mieć przełożenie na konieczność zmiany sposobu finansowania, np. edukacji i służby zdrowia.

Pozytywnym skutkiem starzenia jest to, że pojawia się nisza do zagospodarowania - rynek dóbr i usług dedykowany osobom starszym. W krajach rozwiniętych w praktyce funkcjonuje tzw. srebrna gospodarka, która między innymi korzysta z doświadczeń osób starszych na rynku pracy, a przede wszystkim traktuje ich jako bardzo poważnych konsumentów wyselekcjonowanych dóbr i usług.

\section{Literatura}

Bylok F., 2013, Zachowania konsumpcyjne seniorów na rynku dóbr i ustug, [w:] Kałuża-Kopias D., Szukalski P. (red.), Starzenie się ludności - między demografiq a polityka społeczna, Wydawnictwo Uniwersytetu Łódzkiego, Łódź, s. 140.

Giza A., Sikorska M., 2012, Wspótczesne społeczeństwo polskie, Wydawnictwo Naukowe PWN, Warszawa.

Główny Urząd Statystyczny, 2014, Rocznik demograficzny 2013, http://www.stat.gov.pl (10.01.2015).

Główny Urząd Statystyczny, 2014, Sytuacja demograficzna osób starszych i konsekwencje starzenia się ludności Polski w świetle prognozy na lata 2014-2050, http://www.stat.gov.pl/ (15.01.2015).

Główny Urząd Statystyczny, Bank Danych Lokalnych, http://www.stat.gov.pl (10.01.2015).

Jurek Ł., 2010, Proces demograficznego starzenia jako istotne wyzwanie dla społeczeństwa polskiego w XXI wieku, [w:] Kowalczyk O. (red.), Nauki społeczne, Współczesne społeczeństwa - nadzieje i zagrożenia, Wydawnictwo Uniwersytetu Ekonomicznego we Wrocławiu, Wrocław, s. 70-72.

Jurek Ł., 2012, Ekonomia starzejacego się społeczeństwa, Difin, Warszawa.

Kijak R.J., Szarota Z., 2013, Starość. Między diagnozq a działaniem, Centrum Rozwoju Zasobów Ludzkich, Warszawa.

${ }^{21}$ W. Tyc, wyd. cyt., s. 228. 
Ministerstwo Gospodarki, Pracy i Polityki Społecznej, 2003, Raport Racjonalizacja Wydatków Spotecznych ,Zielona Księga”, http://resources.rybinski.eu (05.01.2015).

MPS, Projekcja wydatków socjalnych na lata 2004-2020, http://www.funduszestrukturalne.gov.pl/informator/npr2/prognozy/Projekcja\%20wydatkow\%20socjalnych\%20w\%201atach\%2020042020\%20\%28MPS\%29.pdf (20.12.2014).

Nyce S.A., Schieber S.J., 2011, Ekonomiczne konsekwencje starzenia się społeczeństw, Wydawnictwo Naukowe PWN, Warszawa.

Stańko D., 2010, Wplyw systemu emerytalnego na gospodarke, http://www.inepan.waw.pl/pliki/studia _ekonomiczne/ stanko.pdf (05.01.2015).

Szukalski P., 2007, Starzenie się ludności a publiczny kontrakt intergeneracyjny, http://dspace.uni.lodz. pl:8080/xmlui/handle/11089/4096 (10.01.2015).

Szukalski P., 2012, Solidarność pokoleń. Dylematy relacji międzypokoleniowych, Wydawnictwo Uniwersytetu Łódzkiego, Łódź.

Toffler A., 1985, Trzecia fala, PIW, Warszawa.

Tyc W., 2007, Ekonomiczne i spoteczne uwarunkowania transformacji rodziny, Wydawnictwo Akademii Ekonomicznej im. Oskara Langego we Wrocławiu, Wrocław. 